Ethiopian Journal of Environmental Studies \& Management 9(Suppl. 1): 841 - 851, 2016.

ISSN:1998-0507

Submitted: May 14, 2016

doi: http://dx.doi.org/10.4314/ejesm.v9i1.4S

Accepted: November 22, 2016

\title{
CONSERVATION IMPLICATIONS OF WEED MANAGEMENT OF LAKE RESERVOIRS ON WILDBIRDS
}

\author{
*ADEYANJU, A.T.1 ${ }^{*}$ AND KAMBAI, C. ${ }^{2,3}$ \\ ${ }^{1}$ Department of Wildlife and Ecotourism Management, University of Ibadan, Nigeria \\ ${ }^{2}$ Federal College of Forestry, Jos, Nigeria \\ ${ }^{3}$ International Institute of Tropical Agriculture, old Oyo road, Moniya, Ibadan
}

\begin{abstract}
Management of weeds around lake reservoirs is often implemented to reduce any possibility of siltation. However, machineries used in weed management have resulted in habitat degradation and geometrical multiplication of weeds by chopping rhizomes and scattering seeds. In general, the removal offers some feedbacks for wildlife around the lake which ought to be taken into account. We determined the effect of weed removal from a lake reservoir on wildbird activity and diversity using two transects $1.2 \mathrm{~km}$ each. Transects were subdivided into 'twelve' 200m sections using a GPS and variables taken into account were: wildbird species present; abundance; species activity; weed parameter ('zero' where cover was less than 10 percent of entire area, 'one' if extent of cover was less than 50 percent and 'two' if cover was greater than 50 percent). Complete removal of weeds significantly affected bird species abundance and richness. Comparison of this survey with previous data reveal that some species, such as Actophilornis africana African jacana have adapted to the removal of weeds while others such as the Gallinula chloropus Common moorhen, are now absent from the lake bank due to weed removal. Therefore, monitoring wildlife population to species holds great value for amplifying management decisions.
\end{abstract}

Key Words: Wildbirds, Weed management, John Craig Lake, Transect, Conservation

\section{Introduction}

Habitat degradation, with the attendant population changes in wildlife species, especially wildbirds have been clearly linked (Lambert, 1992; Dale and Slembe, 2005; Dami et al., 2012; Uwimbabazi and Eilu, 2013). Also, the effects of human degradation on terrestrial habitats have been researched upon in great detail and wildbirds have been used as indicators (Cresswell et al., 2007). However, very little is known on the effects of vegetative cover and/or weed removal from water surface on Afrotropical wildbird species.

Wildbirds are ubiquitous in their use of habitats and have therefore become widely utilized to determine the effects of some landscape alteration and or management practices (Adeyanju et al., 
2009; Dami et al., 2012; Uwimbabazi and Eilu, 2013). Birdss are conspicuous though weed cover removal and intermittent regimes of clearing have varying effects on different bird guilds which is closely associated with foraging habits of the species in question (BirdLife International, 2004; Maclean et al., 2006; Wenny et al., 2011). It is common knowledge that the level of connectivity between other available terrestrial habitats optimum for foraging for wildbirds would play a role in determining their persistence in a degraded landscape after habitat degradation has occurred. Nonetheless, bird diversity indices such as species richness and abundance have been used to measure the effects of habitat degradation (Maclean et al., 2006; Adeyanju et al., 2009; Wenny et al., 2011). In addition, wildlife activity such as foraging and roosting has also been used to demonstrate habitat utilization (Patriquin and Barclay, 2003; Molokwu et al., 2007). Shorebirds such as African jacana Actophilornis africana and Common moorhen Gallinula chloropus are key species around the International Institute for Tropical Agriculture (IITA) John Craig lake which utilize the shore for food (Adeyanju et al., 2012). The site is among the 27 Important Bird Areas in Nigeria and known to hold at least 269 bird species in 64 families (Adeyanju et $a l ., 2014)$. More importantly, wildbirds at the lake provide a number of services for the community which could be categorized mainly into four; recycling or biological control, supporting, cultural or aesthetics and provisioning services (Millenium Ecosystem Assessment, 2003). These services among others showcase that wildlife habitats such as lakes in this study should be given concern when management actions are required in order to prevent losing the services gained freely.

This is the first published survey at the Important Bird Area (IITA) determining the effects of management's removal of weed cover on birds utilizing the shores of the lake. The survey sought to determine whether cover removal would have any effect on abundance, species richness and foraging patterns of wildbirds on the lake. In addition, bird species activity was monitored during the survey and these includes; roosting, flying and feeding. The diversity of birds observed at the shore was compared with previous site data.

\section{Methodology}

Two line transects of $1.2 \mathrm{~km}$ each were placed on each of the two sides of the lake 'west and east', resulting in a total of four transects (Bibby et al., 2000). However only transects on the east side of the lake were surveyed because accessibility without bias on the west side was not possible. In addition to this, each transect was subdivided into twelve $200 \mathrm{~m}$ sections with the aid of a Garmin Global Position System on the east side of the lake. Variables taken during the survey included; bird species present, abundance, activity, presence and extent of Water lily (Nymphaea lotus) coverage was measured as 'zero' where cover was absent, 'one' if extent of cover was less than 50 percent but greater than zero and 'two' if cover was greater than 50 percent; however none of the sections scored three. The number of vehicles, motorcycles, tractors and or persons within $20 \mathrm{~m}$ of transect were monitored and recorded by the observer. 
All bird species in the study were observed with the aid of an $8 \times 42$ binoculars and identified to species with the aid of Helm's field guide to birds of western Africa (Borrow and Demey 2004). Bird activity was scored as roosting, foraging, and flying. Survey was limited to just $30 \mathrm{~m}$ width of the lake margins where most of the weeds and foraging activity were already known to abound and occur. Averagely the survey of each transect did not last more than an hour and each section 10mins. Surveys took place between 08:00hrs and 10:00hrs for ten days $\left(21^{\text {st }}\right.$ of August 2013 and $3^{\text {rd }}$ of September 2013). At the end of the survey, comparisons were made with the aid of statistical tools between abundance and species richness using the weed parameter as an independent variable. The ordering of transects was alternated by the observer to remove the bias of sighting higher number of species on a particular side of the lake.

\section{Result}

An overview of data collected on abundance and species richness of wildbirds is presented in Table 1. Test for normality and equality of variances were carried out prior to determining whether parametric or non-parametric test would be suitable in order to determine differences in sample means. OneSample Kolmogorov-Smirnov test showed that species richness and abundance data were not normally distributed. For Species richness $Z=2.08$, $\mathrm{N}=137, \quad \mathrm{P}<0.01 ;$ and Abundance, $\mathrm{Z}=2.89, \mathrm{~N}=137, \mathrm{P}<0.01$; while Levine's Test of Homogeneity of Variances showed that variances were also not equal. For abundance $\mathrm{F}=9.97, \mathrm{~N}=137$, $\mathrm{P}<0.01$ and species richness $\mathrm{F}=4.34$, $\mathrm{N}=137, \quad \mathrm{P}<0.05$. Non-parametric tests were therefore used for analysis.

Table 1: Overview of data used in analysis

\begin{tabular}{llllllll}
\hline & $\begin{array}{l}\text { Weed } \\
\text { Parameter }\end{array}$ & $\mathrm{N}$ & Mean & $\begin{array}{l}\text { Std. } \\
\text { Deviation }\end{array}$ & \multicolumn{2}{c}{$\begin{array}{c}\text { Std. Error 95\% Confidence } \\
\text { Interval for Mean }\end{array}$} \\
\hline Abundance & 0 & 22 & 10.18 & 8.62 & 1.84 & 6.36 & 14.00 \\
& 1 & 59 & 24.14 & 27.72 & 3.61 & 16.91 & 31.36 \\
& 2 & 38 & 37.53 & 30.91 & 5.02 & 27.37 & 47.69 \\
\multirow{6}{*}{ Richness } & Total & 119 & 25.83 & 27.96 & 2.56 & 20.76 & 30.91 \\
& 0 & 22 & 2.09 & 1.15 & 0.25 & 1.58 & 2.60 \\
& 1 & 59 & 2.75 & 1.23 & 0.16 & 2.43 & 3.07 \\
& 2 & 38 & 3.76 & 1.36 & 0.22 & 3.32 & 4.21 \\
& Total & 119 & 2.95 & 1.39 & 0.13 & 2.70 & 3.20 \\
\hline
\end{tabular}

\section{Effect of weed parameter on bird species} activity, abundance and species richness

Weed parameter did not show any significant effect on bird species activity at the lake; however activity was observed to be relatively higher at the weed parameter level 2 than in either of the other two parameters levels ( 0 and 1$)$.
Kruskal Wallis Test was used since data did not fulfill requirement for parametric tests. The test showed that weed parameter levels at the lake were significant in determining bird species abundance $\left(X^{2}=27.94, \quad \mathrm{df}=2, \quad \mathrm{P}<0.01\right.$; Figure 1 and Table 2). 


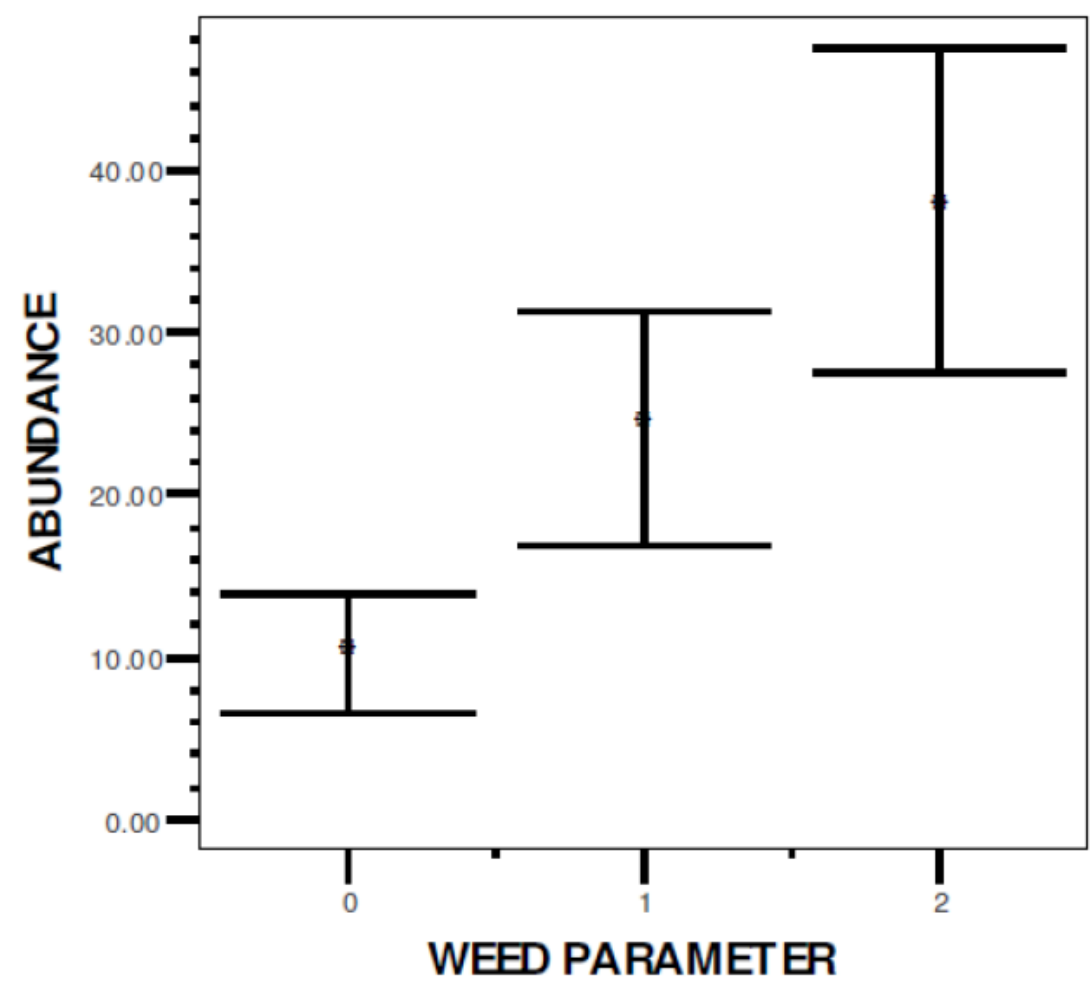

Figure 1: Effect of weed parameter on bird species abundance

Table 2: Pairwise comparison using LSD

\begin{tabular}{|c|c|c|c|c|c|c|c|}
\hline \multirow[t]{2}{*}{$\begin{array}{l}\text { Dependent } \\
\text { Variable } \\
\end{array}$} & \multicolumn{2}{|c|}{ Weed parameter } & Mean Difference (I-J) & Std. Error & Sig. & $\begin{array}{l}95 \% \\
\text { Interval }\end{array}$ & Confidence \\
\hline & (I) & $(\mathrm{J})$ & Lower Bound & Upper Bound & & Upper & Lower \\
\hline & & & & & & Bound & Bound \\
\hline \multirow[t]{3}{*}{ Abundance } & 2 & 0 & 27.35 & 7.10 & $<0.01 *$ & 13.28 & 41.41 \\
\hline & & 1 & 13.39 & 5.51 & $<0.05^{*}$ & 2.47 & 24.31 \\
\hline & 0 & 1 & -0.66 & 0.32 & $<0.05^{*}$ & -1.28 & -0.03 \\
\hline \multirow[t]{2}{*}{ Richness } & 2 & 0 & 1.67 & 0.34 & $<0.01 *$ & 1.00 & 2.34 \\
\hline & & 1 & 1.02 & 0.26 & $<0.01 *$ & 0.50 & 1.54 \\
\hline
\end{tabular}

In the same manner, for species richness, Kruskal Wallis test showed that there was a significant difference (Figure 2 and Table 2) between the three levels of weed parameters on bird species richness $\left(X^{2}=24.70, \mathrm{df}=2, \mathrm{P}=0.01\right)$. 


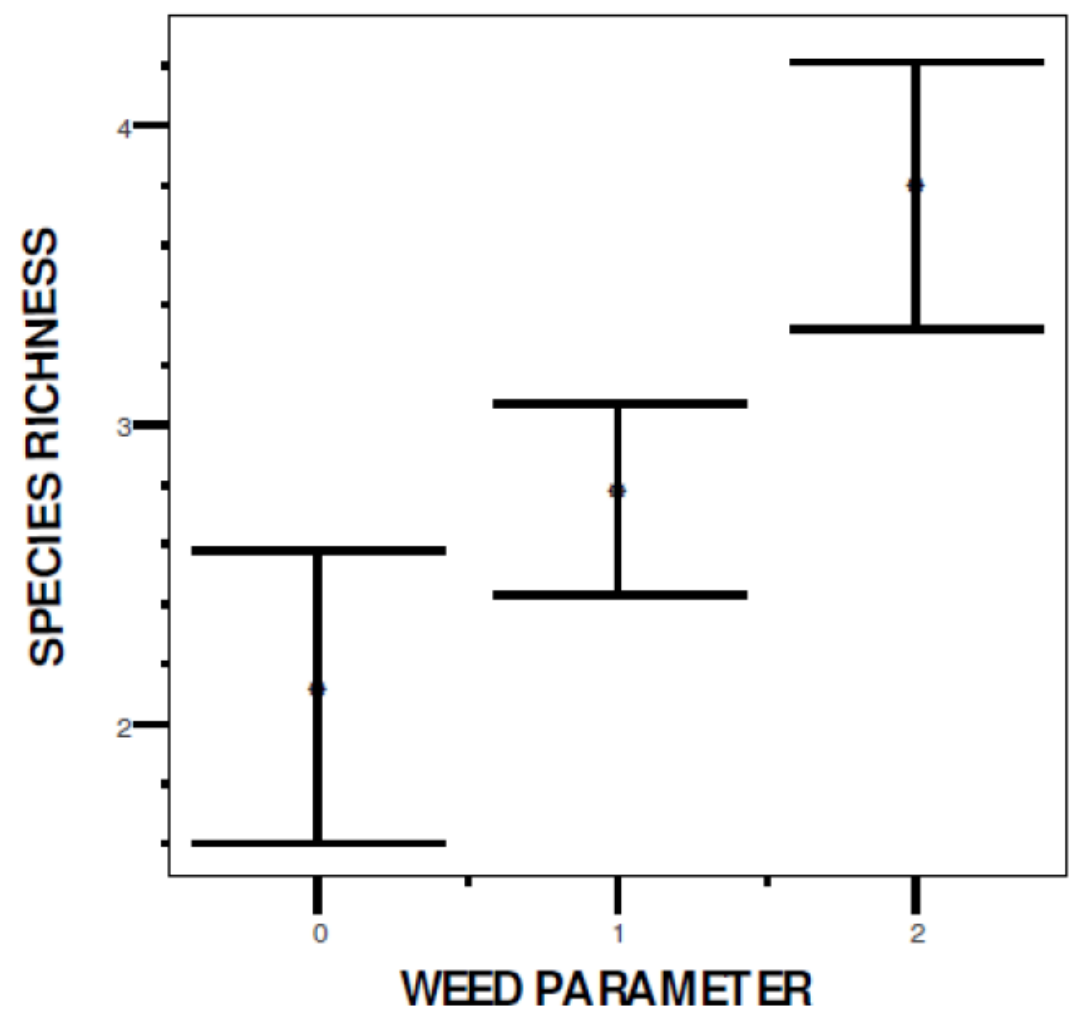

Figure 2: Effect of weed parameter on bird species richness

Table 2: Pairwise comparison using LSD

\begin{tabular}{|c|c|c|c|c|c|c|c|}
\hline \multirow[t]{3}{*}{$\begin{array}{l}\text { Dependent } \\
\text { Variable }\end{array}$} & \multicolumn{2}{|c|}{ Weed parameter } & \multicolumn{2}{|c|}{ Mean Difference (I-J) Std. Error } & Sig. & $\begin{array}{l}95 \% \\
\text { Interval }\end{array}$ & Confidence \\
\hline & (I) & $(\mathrm{J})$ & Lower Bound & Upper Bound & & Upper & Lower \\
\hline & & & & & & Bound & Bound \\
\hline \multirow[t]{3}{*}{ Abundance } & 2 & 0 & 27.35 & 7.10 & $<0.01 *$ & 13.28 & 41.41 \\
\hline & & 1 & 13.39 & 5.51 & $<0.05^{*}$ & 2.47 & 24.31 \\
\hline & 0 & 1 & -0.66 & 0.32 & $<0.05^{*}$ & -1.28 & -0.03 \\
\hline \multirow[t]{2}{*}{ Richness } & 2 & 0 & 1.67 & 0.34 & $<0.01 *$ & 1.00 & 2.34 \\
\hline & & 1 & 1.02 & 0.26 & $<0.01^{*}$ & 0.50 & 1.54 \\
\hline
\end{tabular}

*The mean difference is significant at the .05 level.

Effect of time of day on bird species abundance and species richness

Mann-Whitney U Test showed that time of day did not significantly influence bird species abundance and species richness between the two hours within 08:00 to 10:00 hrs during which the bird survey was carried out at the lake (only one section was surveyed at the hour of 10 the first day, hence not included in the Mann-Whitney $U$ test). Nonetheless, average species abundance between 09:00 to 10:00hrs was relatively higher than that between 08:00 and 09:00hrs. On the other hand, bird species richness was relatively higher between 08:00 to 09:00hrs than between 09:00 and 10:00hrs. For species richness $Z=-$ 
$0.79, \mathrm{P}=0.43$ and for abundance $\mathrm{Z}=-0.29$, $\mathrm{P}=0.77$.

Effect of transect on bird species abundance and species richness

Mann-Whitney U Test showed that the two transects did not significantly differ in species abundance and species richness. For species richness $\mathrm{Z}=1686.0$, $\mathrm{P}=0.65$ and for abundance $\mathrm{Z}=1609.0, \mathrm{P}>$ 0.05 . Nonetheless the bird species richness and abundance in transect 1 were both relatively higher than those in transect 2 respectively. In addition the average movement of vehicles and cycles did not significantly differ between the two transects. For movement of motorcycles Mann-Whitney U Test, Z= -
$0.05, \mathrm{P}>0.05$ and for motor-vehicles $\mathrm{Z}=-$ $0.55, \mathrm{P}>0.05$.

Effect of section on bird species abundance and species richness

The error bars in Figure 3 and 4 show clearly the effect of removal of weeds from each section; section 800 in Figure 3 and 4 clearly show that section does have an influence on bird species abundance and richness respectively. A Kruskal Wallis Test showed that section was significant in determining species abundance and species richness around the lake. For species richness, $X^{2}=48.21$, df $=11, \quad P>0.05$ and for abundance, $X^{2}=59.32, \mathrm{df}=11, \mathrm{P}>0.01$.

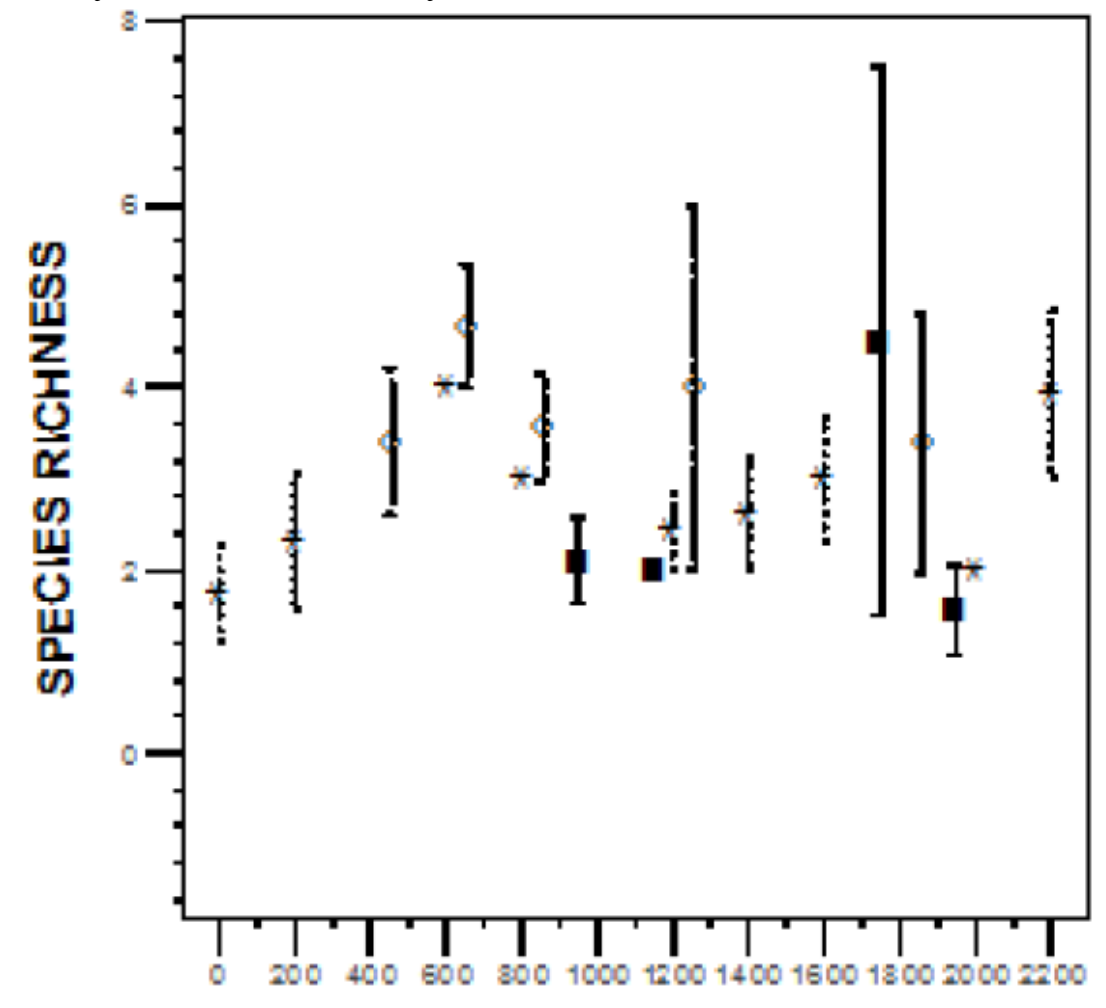

SECTION

Figure 3: Effect of section on bird species richness 


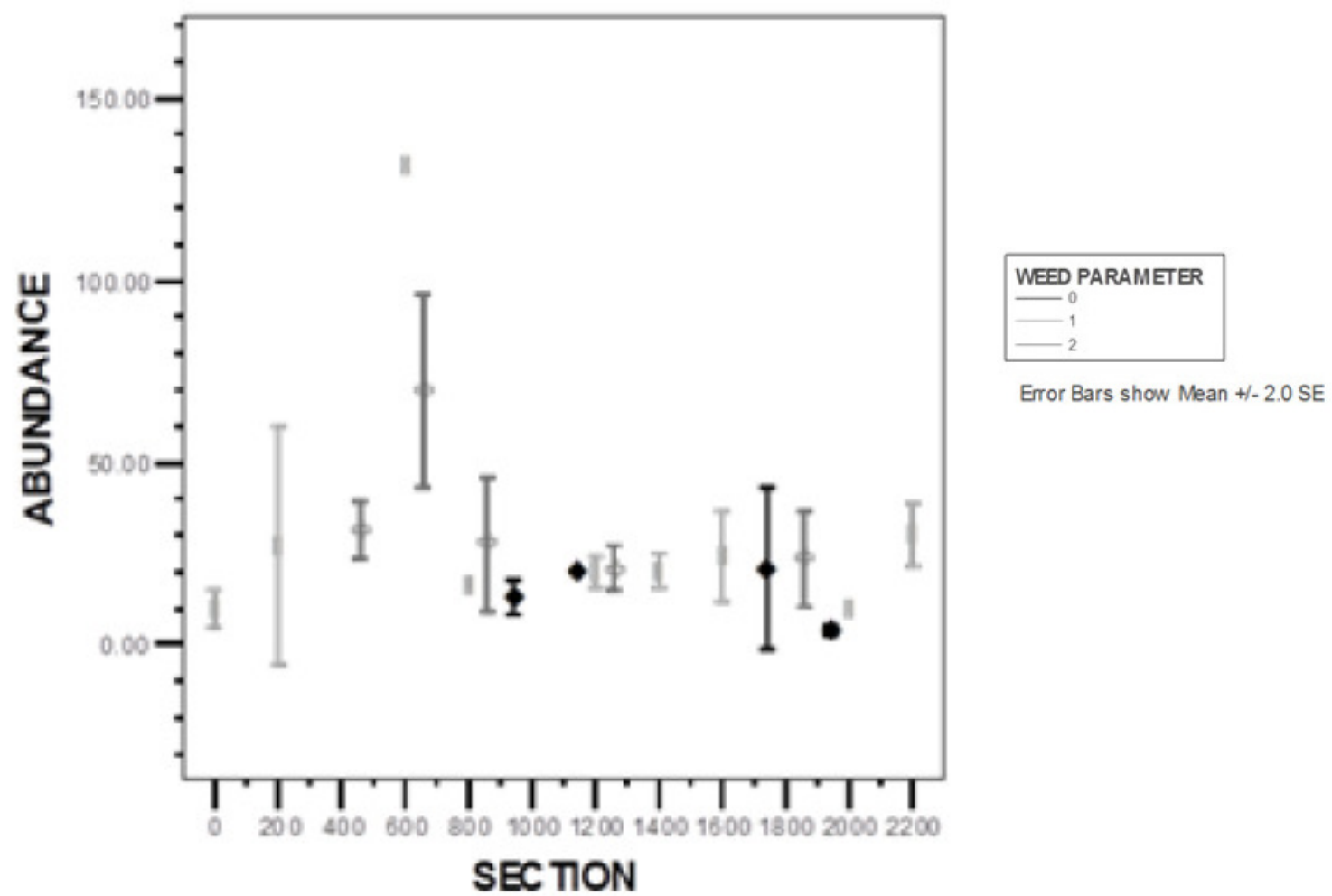

Figure 4: Effect of section on bird species abundance

\section{Discussion}

Effect of weeding on bird species activity, abundance and species richness

Bird species activities surveyed included; flying, feeding and roosting at the lake. However, bird activity was not significantly influenced by vehicular movement on the road. Though birds may move initially, once the disturbance is lifted, they tend to return to their initial preferred location and activity. Bird species abundance and species richness on the other hand are significantly affected by weed removal. Worldwide, weeds are considered to be one of the most important threats to biodiversity conservation (Bremner and Park 2007) and so extensive resources have been allocated to their management (Ewel and Putz, 2004; Sinden et al., 2004; Pimentel et al., 2005). Conversely our findings reveal that where weeds are not removed more birds are observed in terms of numbers and species This study particularly focused on species of birds utilizing a narrow strip of the lake shore margin therefore eliminating other species which might be generalists (and not affected by the weed removal). Therefore bird species that require this niche for their survival will be affected by the complete removal of weeds from the lake, while species capable of adapting to this change will increase (Waltert et al., 2005). When previous data was compared Gallinula chloropus Common moorhen, once common on the fringes of the lake are now absent from the lake bank environs due to weed removal. However, since weeding was random there were not areas which could be said to be always weeded and other 
areas which were not weeded. An inclusion of the west bank of the lake to the survey would have introduced bias as cover in the area would prevent the observer from positively identifying species that utilize the area.

Weed parameter level 2 resulted in the highest support for both bird species abundance and richness. Though weed parameter level 1 did support significantly higher species richness and abundance than the weed parameter level 0 . This means that in sections where there were more weeds more bird species diversity resulted. This is expected as bird species diversity is known to increase with habitat heterogeneity. Furthermore, despite the negative effects of weeds, globally, there is growing evidence that weeds benefit wildlife under certain circumstances as observed in our study. Weeds may represent a food source (Lawrie, 2002); provide habitat for breeding (Nias, 1986), roosting and perching (Fisher and Goldney, 1997); and refuge from predators (Brown et al., 1991; Sanderson and Kraehenbuehl, 2006). Weeds become particularly important for wildlife when alternative native habitat is limited (Sutter et al., 1995; Graves and Shapiro, 2003), especially for threatened species (Date et al., 1996; Schmidt et al., 2009)

\section{Effect of time of day on bird species abundance and species richness}

It is generally known that bird species activity falls with increase in hour of day (Adeyanju et al., 2009, Manu and Cresswell, 2007). However time of day on the other hand did not show any significant effect on the bird species richness and abundance between the time limits for our survey. This shows that there was no bias in using that time period on our resulting inference of an impact of weed removal. In addition, the same 'observer' was used to detect bird species at the lake after ensuring the 'observer' was good in identifying all the bird species on site.

\section{Effect of transect on bird species abundance and species richness}

It is important to note that though transect 1 did support more bird species richness and abundance, there was a higher weed removal activity on transect 1 than on transect 2. However as soon as weeds were removed from a particular section they began resprouting. It was also observed that weed removal was never successful at clearing all the weeds (weed parameter level zero does not mean no weeds) and though transect 1 experienced more weed activity more bird diversity was observed. In addition, some sections supported higher bird species diversity than others and this could be supported by the same point, availability of food and cover.

\section{Bird species richness}

The three most frequent bird species in this survey were African jacana, Vanellus spinosus Spur-winged plover and Tringa hypoleucos Common sandpiper. The first two species are already known to be using the site as a breeding ground and this could serve as a basis for informing that they are responding well to management activity. Nonetheless it must be understood that not all species are naturally conspicuous, others even though numerous, are shy and will not be easily sighted and may be thought to be rare. African jacana and Spur-winged plovers are well adapted to human presence and conspicuous. Others like Amaurornis flavirostra African black crake are abundant but shy and therefore 
observed less frequently. Comparison of this survey with previous data reveal that Common moorhen, are now absent from the lake bank environs due to weed removal. They could be unable to hold up to the consistent clearing of weeds on the lake hence necessitating their move to other areas that are not often cleared.

Bird species frequent at the site but not observed during the survey include Motacilla flava Yellow wagtails which are Palearctic migrants and this could be explained by season. Intra-African migrants observed in low numbers include Ardeola ralloides Squacco heron of which only a single individual was sighted. Others not sighted at all include Tringa glareola Wood sandpiper, Nycticorax nycticorax Black-crowned night heron and Ixobrychus minutus Little bittern. They are seasonally available at the site but were absent during this survey.

Bird species with live young observed during the survey are African jacana and Porphyrio alleni Allens' gallinule. Though a previous survey observed Spur-winged plovers and Vanellus albiceps White-headed lapwings breeding and raising young successfully in April. This further shows that timing of breeding is not obligately defined to the same period in all species though some others may choose to synchronize breeding to particular periods. Dendrocygna viduata Whitefaced whistling ducks numbers have declined as they are also migratory and numbers will increase in other periods of the year.

\section{Conclusion}

Though previous monitoring on the lake in 2009 showed no effect of weed removal from the lake this present review has generated reason for concern on management activity at the lake. It is important to note that, though variation in methodology is obvious when comparing the two surveys, weed removal does have both short-term and long term effects on wild bird population. Therefore caution should always be made when interpreting species richness and abundance data because very sparse information on longterm studies is available on such in issues around this region. The changes could be minute and they could also be conspicuous, none the less time will tell how each species local population present on site adapts to the changes. This furthermore makes it pertinent to keep long term data on management activities so that over time policies can be reviewed from this sort of monitoring.

\section{Recommendations}

Monitoring of wildbird population at lower thresholds of management decision will bring out to the open, more of the effects of management decisions than large-scale monitoring. Also effects on wild bird population and on individuals are different and the final decision should be what is good for the population and not only the individual. This is both cheaper and cost effective in the long run. Piles of weed removed from the lake should not be left at the edges of the lake as this not only inhibit view of tourists but also serve as seed banks for increasing the dispersal of weeds across the lake. Water weeds are good in removing excess nutrients from water bodies but leaving them at the edges only serves to backstab management effort in the first place. Currently, a combination of reforestation and gradual weed 
removal in response to the presence of a wildlife-weed relationship is recommended (Sogge et al., 2008; Carlos and Gibson, 2010). Reforestation of the edges of the lake should be encouraged as this will provide windbreaks, prevent siltation of the lake and also provide shade for nature viewing tourists.

\section{Acknowledgements}

The authors are grateful to the Forest project of the International Institute of Tropical Agriculture for initiating and supporting the survey. We acknowledge financial and moral support of the Institute of Immunology, Laboratoire National De Santé who provided funding for part of TAA's $\mathrm{PhD}$ program at the University of Ibadan.

\section{References}

Adeyanju, A.T., Shiiwua, M. and Ottosson, U. (2009). Effects of introduced tree plantations on the density and diversity of bird species in some parts of the Jos Plateau, Nigeria. ROAN Journal, 5(1): 63-75.

Adeyanju, A.T., Ottosson, U. and Shiiwua, M. (2012). Common birds of IITA. IITA Publishing, Ibadan Nigeria.

Adeyanju, A.T., Ottosson, U., Adeyanju, T.E., Omotoriogun, T.C., Hall, P., Manu, S., Alabi, T., Lameed, G.A. and Bown, D. (2014). Birds of the International Institute for Tropical Agriculture campus, a stronghold of avian diversity in the changing Ibadan area (Nigeria) over the last 50 years. Malimbu,s 36(2):76-105.

Bibby, C.J., Burgess, N.D., Hill, D.A. and Mustoe, S.H. (2000). Bird Census techniques. Academic Press, London.

Birdlife International (2004). State of the world's birds 2004: indicators for our changing world. Cambridge, UK: BirdLife International.

Borrow, N. and Demey, R. (2004). A Guide to the Birds of Western Africa. Princeton University press, New Jersey. 832pp.

Bremner, A. and Park, K. (2007). Public attitudes to the management of invasive non-native species in Scotland. Biological Conservation, 139: 306-314.

Brown, P.R., Wallis, R.L., Simmons, D. and Adams, R. (1991). Weeds and wildlife. Plant Protection Quarterly, 6(3): 150-153.

Carlos, E.H. and Gibson, M. (2010). The habitat value of gorse Ulex europaeus L. and hawthorn Crataegus monogyna jacq. for birds in Quarry Hills bushland park, Victoria. The Victorian Naturalist 127(4): 115-123.

Cresswell, W.R.L., Wilson, J.M., Vickery, J., Jones, P. and Holt, S. (2007). Changes in densities of Sahelian bird species in response torecent habitat degradation. Ostrich, 78(2): 247-253.

Dami, F.D., Mwansat, G.S. and Manu, S. (2012). The effects of forest fragmentation on species richness on Obudu Plateau, south-eastern Nigeria. Afr. J. Ecol., 51:32-36

Date, E.M., Recher, H.F., Ford, H.A. and Stewart, D.A. (1996). The conservation and ecology of rainforest pigeons in northeastern New South Wales. Pacific Conservation Biology, 2: 299-308.

Ewel, J. and Putz, F. (2004). A place for alien species in ecosystem restoration. Frontiers in Ecology and the Environment, 2(7): 354-360.

Fisher, A. and Goldney, F. (1997). Use by birds of riparian vegetation in an extensively fragmented landscape. 
Pacific Conservation Biology 3: 275288.

Graves, S.D. and Shapiro, A.M. (2003). Exotics as host plants of the California butterfly fauna. Biological Conservation 110(3): 413-433.

Lawrie, S. (2002). An audit system to account for birds and mammals utilising weeds species. In: Australian weeds conference, 13. Organised by Plant Protection Society of Western Australia. September 8-13, 2002. Pp. 108-111

Patriquin, K.J. and Barclay, B. M. R. (2003). Foraging by bats in cleared, thinned and unharvested boreal forest. Journal of Applied Ecology, 40 (4):646-657

Maclean, I.M.D., Hassel, M., Boar, R. and Lake, L.R. (2006). Effects of disturbance and habitat loss on papyrus dwelling passerines. Biological Conservation, 131: 349358.

Manu, S. and Cresswell, W. (2007). The effects of forest fragmentation on Palearctic migrants in south western Nigeria. Ostrich, 21-28.

Millenium Ecosystem Assement (MEA) (2003). Ecosystem and human wellbeing: A framework for assesment. Island Press. Washington D.C.

Molokwu, M.N., Olsson, O. and Ottosson, U. (2007). Feeding behaviour of birds foraging on predictable resources in habitats of different quality Ostrich, Journal of African Ornithology, 7 (2): 295-298.

Nias, R. (1986). Nest site characteristics and reproductive success in the superb fairy-wren. Emu, 86: 139-144.

Pimentel, D., Zuniga, R. and Morrison, D. (2005). Update on the environmental and economic costs associated with alien-invasive species in the United
States. Ecological Economics, 25: 273-288.

Sanderson, K.J. and Kraehenbuehl, J. (2006). Southern brown bandicoots Isoodon obesulus obesulus in Belair National Park. Australian Mammalogy, 28: 147-152.

Schmidt, B., Renowden, C. and Quin, D. (2009). Southern brown bandicoot strategic management plan for the former Koo Wee Rup swamp area. Fairfield: Ecology Australia. Sinden, J., Jones, R., Hester, R., Odom, D., Kalisch, C., James, R. and Cacho, O. (2004). The economic impact of weeds in Australia. Adelaide: CRC for Australian weed management.

Sogge, M.K., Sferra, S.J. and Paxton, E.H. (2008). Tamarix as habitat for birds: implications for riparian restoration in the southwestern United States. Restoration Ecology 16(1): 146-154.

Sutter, G.C., Troupe, T. and Forbes, M. (1995). Abundance of Baird's sparrows, Ammodramus bairdii, in native prairie and introduced vegetation. Ecoscience, 2(4): 344348.

Uwimbabazi, M. and Eilu, G. (2013). Avian frugivore assemblages on Celtis gomphophylla, Baker, in Budongo Forest Reserve, Uganda. Afr. J. Ecol., 52: 97-102

Waltert, M., Bobo, K. S., Sainge, M. N., Fermon, H. and Muhlenberg, M. (2005). From forest to farmland; habitat effects on afrotropical forest bird diversity. Ecological Applications, 15(4): 1351-1366.

Wenny, D.G., De Vault, T.L., Johnson, M. D., Cagan, D.K and Sekercioglu, C.H. (2011). Perspectives in ornithology, the need to quantify ecosystem services provided by birds. The Auk, 128.1:1-14. 